\title{
Pengaruh Komposisi Media Tanam dan ZPT Air Kelapa terhadap Pertumbuhan setek pucuk Jeruk Kacang (Citrus reticulata Blanco).
}

\section{The Influence of Planting Media Composition and Hormonal Growth of Coconut Water to the Shoot Cuttings Jeruk Kacang ( Citrus reticulata Blanco).}

\author{
Rivo Yulse Viza dan Arista Ratih
}

Prodi. Pendidikan Biologi, STKIP YPM Bangko,

${ }^{*}$ Korespoden: rivoyulse02@gmail.com

\begin{abstract}
'Limau kacang' has been a specialty crop in the Solok region of West Sumatra. The spread of Citrus reticulata Blanco is still experiencing barriers and the population is threatened with extintion. Overcome the problem is done propagation of Citrus reticulata Blanco vegetatively with shoot cutting. The experiment on the influence of different growing media and hormonal growth of coconut water to the shoot cutting of Citrus reticulata Blanco has been accomplished at kanagarian Kacang Kecamatan X Koto Singkarak, Kabupaten Solok, this experiment started in June to October 2017. This research used Randomized Completely Block Design (RCBD) Factorial. The first factor was four different growing media (soil, soil : manure, soil : husk, soil : sand) while the second factor was two level coconut water concentrations $(0 \%$ and $25 \%)$ with three replication. Variables analiyzed were the survival percentage, while emerging shoots, shoot length, number of leaf, number of shoot, number of root and root length. The result of this research showed that A3B0 treatment (planting media soil : manure without coconut water as hormonal growth) gave the best influence to the growth of shoot cuttings of Citrus reticulata Blanco.
\end{abstract}

Keywords: Citrus reticulata Blanco, coconut water, planting media, shoot cuttings

\section{Pendahuluan}

Mandarin "Limau kacang" telah menjadi tanaman khas di wilayah Solok, Sumatera Barat. Dari penelitian Nasir, N et al (2017) diketahui bahwa karakter morfologi Limau Kacang dan ponkan hampir sama. Dua aksesi Limau Kacang menunjukkan pola pita identik atau sangat mirip dengan Ponkan (Citrus reticulata Blanco) dalam analisis SRAP. Jadi Limau kacang adalah jenis Ponkan.

Penyebaran tanaman jeruk kacang masih mengalami hambatan dan populasinya terancam punah akibat serangan CVPD (Citrus Vein Phoem Degeneration). Untuk mengatasi hal tersebut dilakukan perbanyakan tanaman jeruk kacang dengan dua cara yaitu secara generarif dan vegetatif. Perbanyakan secara vegetatif yang biasa digunakan adalah stek. Dalam usaha perbanyakan tanaman jeruk kacang dengan stek yang menjadi permasalahan adalah bagaimana mendapatkan bahan stek yang mempunyai kecepatan tumbuh yang tinggi dan persentase perakaran yang lebih tinggi. Dalam penelitian ini dilihat pengaruh komposisi media tanam dan ZPT air kelapa terhadap pertumbuhan stek pucuk jeruk kacang (Citrus reticulata Blanco).

Zat pengatur tumbuh adalah senyawa organik bukan nutrisi yang dalam konsentrasi rendah dapat mendorong, menghambat, atau secara kualitatif mengubah pertumbuhan dan perkembangan tanaman (Widyastuti dan 
Jurnal Biologi Universitas Andalas (J. Bio. UA.)

6(2) - September 2018: 98-106 (ISSN : 2303-2162)

Tjokrokusumo, 2006). Zat pengatur tumbuh yang digunakan dalam penelitian ini yaitu air kelapa. Air kelapa memiliki kandungan kalium cukup tinggi sampai mencapai $17 \%$. Selanjutnya Kristina dan Syahid (2012) menyatakan air kelapa mengandung vitamin dan mineral. Hasil analisis menunjukkan bahwa air kelapa tua dan muda memiliki komposisi vitamin dan mineral yang berbeda. Menurut Lawalata (2011) bahwa air kelapa mengandung hormon auksin dan sitokinin. Kedua hormon tersebut digunakan untuk mendukung pembelahan sel sehingga membantu pembentukan tunas dan pemanjangan batang. Menurut Pamungkas dkk. (2009) auksin akan membantu sel untuk membelah secara cepat dan berkembang menjadi tunas dan batang. Selain mengandung auksin dan sitokinin air kelapa juga mengandung nutrisi yang dibutuhkan oleh tanaman. Ketersediaan nutrisi bagi tanaman sangat penting untuk proses pertumbuhan. Hasil Penelitian Fanesa (2011) mendapatkan bahwa pemberian zat pengatur tumbuh air kelapa muda $25 \%$ memberikan pengaruh yang terbaik terhadap pertumbuhan stek pucuk jeruk kacang.

Selain zat pengatur tumbuh, media tumbuh juga memberikan pengaruh yang sangat nyata terhadap persentase hidup setek jeruk. Penelitian Oksana, dkk (2011) mengenai peranan berbagai macam media tumbuh bagi pertumbuhan stek daun jeruk Japanche citroen memberikan pengaruh yang sangat nyata terhadap persentase hidup akar yang mana untuk keberhasilan pertumbuhan stek daun jeruk J.C sampai tahap diferensiasi akar media tanah lebih baik dari pada media pasir. Media tanam yang baik adalah media yang mampu menyediakan air dan unsur hara dalam jumlah cukup bagi pertumbuhan tanaman. Hal ini dapat ditemukan pada tanah dengan tata udara yang baik, mempunyai agregat mantap, kemampuan menahan air yang baik dan ruang untuk perakaran yang cukup. Berbagai jenis media tanam dapat kita gunakan, tetapi pada prinsipnya kita menggunakan media tanam yang mampu menyediakan nutrisi, air, dan oksigen bagi tanaman. Tanah merupakan hasil transformasi zat-zat mineral dan organik di muka daratan bumi (Sutanto, Rahman. 2009). Dapat dikatakan bahwa tanah adalah sumber utama penyedia zat hara bagi tumbuhan. Penggunaan media yang tepat akan memberikan pertumbuhan yang optimal bagi tanaman.

Hipotesis pada penelitian ini adalah Komposisi media tanam dan ZPT air kelapa dapat memberikan pengaruh terhadap pertumbuhan stek pucuk jeruk kacang (Citrus reticulata Blanco.).

\section{Bahan dan Metode}

Alat yang digunakan antara lain pisau okulasi, cangkul, sekop kecil, paku, timbangan, gembor, handsprayer, meteran, gunting, gelas ukur, thermometer, kamera, mistar, alat tulis. Bahan yang akan digunakan antara lain tanaman jeruk yang diambil bagian pucuk, aquades, tanah andosol, kompos, polibag ukuran $15 \times 20 \mathrm{~cm}$, kertas label, Curater 3GR, fungisida Dithane M45, Plastik Hitam, plastik transparan, paranet dan kayu bulat.

Rancangan yang digunakan dalam percobaan ini adalah Rancangan Acak Kelompok (RAK) faktorial $4 \times 2$. Faktor pertama (A) yaitu macam-macam media tumbuh stek (A) dan faktor kedua (B) adalah konsentrasi air kelapa. Adapun perlakuan pada percobaan ini adalah:

1. Media tumbuh stek (A), yang terdiri dari 4 macam

A1 = Media Tanah

A2 = Media Campuran tanah dan sekam perbandingan 2:1

A3 = Media Campuran tanah dan pupuk kandang perbandingan 1:1

A4 = Media Campuran tanah dan pasir perbandingan 2:1

2. Konsentrasi air kelapa (B), yang terdiri dari 2 taraf

B0 = Tanpa zat pengatur tumbuh air kelapa

$\mathrm{B} 1$ = Dengan zat pengatur tumbuh air kelapa $25 \%$ 
Jurnal Biologi Universitas Andalas (J. Bio. UA.)

6(2) - September 2018: 98-106 (ISSN : 2303-2162)

Dalam percobaan ini terdiri dari 8 perlakuan, setiap perlakuan diulang sebanyak tiga kali sehingga terdapat 24 plot percobaan. Setiap perlakuan terdiri dari 5 stek sehingga jumlah seluruhnya 120 stek.

Tabel 1. Kombinasi Perlakuan

\begin{tabular}{c|r|r|r|c}
\hline \multirow{2}{*}{$\begin{array}{c}\text { ZPT Air } \\
\text { Kelapa }\end{array}$} & \multicolumn{4}{|c}{ Komposisi Media Tanam } \\
\cline { 2 - 5 } & A1 & A2 & A3 & A4 \\
\hline B0 & A1B0 & A2B0 & A3B0 & A4B0 \\
\hline B1 & A1B1 & A2B1 & A3B1 & A4B1 \\
\hline
\end{tabular}

Penelitian ini dilakukan dalam 3 tahap, yaitu tahap persiapan media tanam dan Pembuatan ZPT Air Kelapa. Pembuatan media tanam dengan komposisi sebagai berikut: media tanah, media campuran tanah dan sekam, media campuran tanah dan pupuk kandang, media campuran tanah dan pasir. ZPT air kelapa muda yang digunakan adalah kelapa muda yang berasal dari pohon yang sama, berwarna hijau dengan ciri-ciri warna kulit buah mulus dan licin, bebas dari hama dan penyakit, enodpermnya masih lunak dan tipis, serta mempunyai serabut yang kasar. Endosperm yang masih lunak dan tipis diremas dengan air kelapa tersebut, didapatkan campuran endosperm dan air kelapa muda. Kemudian diencerkan dengan aquades sampai konsentrasi $25 \%$. Untuk konsentrasi $25 \%$ dilakukan dengan cara mengambil campuran air kelapa muda tersebut sebanyak $25 \mathrm{ml}$, kemudian ditambahkan aquades $75 \mathrm{ml}$ sehingga volume larutan air kelapa muda $25 \%$ menjadi $100 \mathrm{ml}$.

Tahap kedua yaitu pengambilan bahan stek dan penanaman. Tanaman jeruk kacang yang diambil adalah bagian pucuk pada ruas ke 6 dari atas. Panjang stek pucuk $\pm 20 \mathrm{~cm}$ sekitar 6 ruas. Bagian bawah stek dipotong miring. Pada stek tersebut terdapat daun 2 lembar daun yang dipotong $2 / 3$ bagiannya. Setelah dilakukan pemotongan pada tunas, lalu bagian pangkal stek direndam pada larutan air kelapa muda dengan konsentrasi $25 \%$ selama 1 jam. Kemudian ditanam pada media tanam yang berbeda yaitu pasir, tanah dan sekam bakar. Sebelum dilakukan penanaman, media tanam disiram terlebih dahulu sampai jenuh air. Hal ini dimaksudkan agar bibit tidak mudah layu. Kemudian baru ditanam hasil stek pucuk jeruk kacang pada media tanam yang tersedia. Cara penanaman stek pertama tama harus dibuat lobang tanam dengan diameter \pm 4 $\mathrm{cm}$ atau sepanjang stek yang akan dibenamkan agar zat pengatur tumbuh yang diberikan tetap terjaga pada saat penanaman. Masukkan pangkal stek ke dalam tanah sedalam 2 ruas setelah itu ditutup dengan tanah hingga tanaman tegak kokoh. Penanaman dapat dilakukan pada sore hari.

Tahapan yang terakhir yaitu pengamatan. Parameter yang diamati adalah persentase bibit hidup, waktu muncul tunas, jumlah tunas, panjang tunas, jumlah daun, panjang akar dan jumlah akar. Hasil pengamatan dianalisa secara statistik dengan menggunakan Two Way ANOVA dengan signifikansi 0.05 atau 5\%. Apabila hasil analisa menunjukkan adanya pengaruh antar perlakuan karena interaksinya yang memiliki nilai signifikansi $<0.05$, sehingga perlu dilanjutkan dengan uji Jarak Duncan (5\%). Data-data yang tidak memenuhi kaidah statistik dianalisis secara deskriptif.

\section{Hasil dan Pembahasan}

\section{Persentase Bibit Hidup}

Persentase bibit hidup stek pucuk jeruk kacang (Citrus reticulata Blanco) dengan komposisi media dan ZPT air kelapa diamati pada minggu ke 84 . Berdasarkan hasil analisa statistik menggunakan Two Way ANOVA dengan signifikansi 0.05 atau 5\% dapat diketahui bahwa interaksi antara Komposisi media dan ZPT air kelapa memiliki pengaruh secara signifikan terhadap waktu munculnya tunas stek pucuk jeruk kacang (Citrus reticulata Blanco). Hal ini ditunjukkan oleh $\mathrm{F}_{\text {hitung }}>\mathrm{F}_{\text {tabel }}$ pada interaksi antara variasi komposisi media dan ZPT air kelapa yaitu $3,737>3,34$ artinya perlakuan 
Jurnal Biologi Universitas Andalas (J. Bio. UA.)

6(2) - September 2018: 98-106 (ISSN : 2303-2162)

komposisi media dan ZPT air kelapa memberikan pengaruh nyata terhadap persentase bibit hidup stek pucuk. Karena faktor komposisi media dan ZPT air kelapa memberikan pengaruh nyata, maka untuk mengetahui perlakuan terbaik dilakukan uji jarak Duncan dengan signifikansi 5\%. Hasil uji lanjut Duncan terhadap persentase bibit yang hidup dapat dilihat pada Tabel 4 .

Tabel 2. Hasil Uji Jarak Duncan Interaksi Komposisi Media dan ZPT Air Kelapa Terhadap Persentase Bibit Hidup (\%)

\begin{tabular}{lcc}
\hline \multirow{2}{*}{ Komposisi Media } & \multicolumn{3}{c}{ Persentase Bibit Hidup (\%) } \\
\cline { 2 - 4 } & ZPT air kelapa & Tanpa ZPT \\
\hline Tanah & $80 \quad$ a & $53,5 \mathrm{c}$ \\
\hline Tanah + Sekam & $46,7 \mathrm{~cd}$ & $40 \quad \mathrm{~d}$ \\
\hline $\begin{array}{l}\text { Tanah + Pupuk } \\
\text { kandang }\end{array}$ & $86,7 \mathrm{a}$ & $60 \quad \mathrm{~b}$ \\
\hline Tanah + Pasir & $80 \quad \mathrm{a}$ & $80 \quad \mathrm{a}$
\end{tabular}

Keterangan : Angka yang diikuti oleh huruf yang sama pada setiap kolom untuk setiap parameter yang

diamati, tidak berbeda nyata pada taraf $5 \%$.

Dari Tabel 2 dapat diketahui bahwa penggunaan media campuran tanah dan pupuk kandang (1:1) tanpa ZPT air kelapa memberikan hasil persentase bibit hidup stek yang berbeda nyata dengan perlakuan yang lainnya sebesar $60 \%$. Perlakuan yang memiliki persentase bibit hidup paling tinggi terdapat pada perlakuan dengan penggunaan media campuran tanah dan pupuk kandang (1:1) dengan ZPT air kelapa yaitu $86,7 \%$. Persentase bibit hidup pada penggunaan media campuran tanah dan pupuk kandang (1:1) dengan ZPT air kelapa tidak berbeda nyata dengan penggunaan media tanah dengan ZPT Air kelapa, penggunan media campuran tanah dan pasir (2:1) tanpa ZPT air kelapa dan penggunan media campuran tanah dan pasir (2:1) dengan ZPT air kelapa. Menurut Manner et al (2006), tanaman jeruk dapat tumbuh dengan baik pada $\mathrm{pH}$ 5-8. Jumlah bibit yang hidup sangat dipengaruhi oleh kandungan bahan makanan yang terdapat pada media tanam. Dari analisis sifat kimia bahan penyusun media tanam dapat diketahui bahwa sekam bakar memiliki kandungan $\mathrm{N}, \mathrm{P}$ dan $\mathrm{K}$ lebih rendah dibandingkan media tanah dan pupuk kandang. Data kriteria sifat-sifat kimia tanah Pusat Penelitian Tanah dan Agroklimat (1994) menyatakan tanah memiliki pH 6,9 dan komposisi C ; N ; $\mathrm{P}$; K (1,28\%; $0,13 \% ; 10,3 \% ; 0,15 \%)$, pupuk kandang memiliki $\mathrm{pH} 8,3$ dan komposisi N ; P ; K (2,04\%; 0,76\%; $0,82 \%$ ), sedangkan sekam bakar memiliki $\mathrm{pH} 7,4$ dan komposisi C ; N ; P ; K (29,95\%; 0,38\%; $0,12 \% ; 0,65 \%)$.

Faktor lain yang menunjang pertumbuhan meliputi air, udara, unsur hara dan penyakit. Sesuai dengan pendapat Bridwell (1979) yang mengatakan bahwa tanaman memerlukan kondisi media tumbuh yang baik untuk menunjang pertumbuhan. Apabila salah satu faktor tersebut berada dalam kondisi yang kurang menguntungkan maka akan mengakibatkan terhambatnya pertumbuhan tanaman.

\section{Waktu Muncul Tunas.}

Berdasarkan hasil analisa statistik menggunakan Two Way ANOVA dengan signifikansi 0.05 atau 5\% dapat diketahui bahwa interaksi antara Komposisi media dan ZPT air kelapa berpengaruh secara signifikan terhadap waktu munculnya tunas stek pucuk jeruk kacang (Citrus reticulata Blanco). Hal ini ditunjukkan oleh $F_{\text {hitung }}>F_{\text {tabel }}$ pada interaksi antara variasi komposisi media dan ZPT air kelapa yaitu 75,157 $>$ 3,34 artinya perlakuan komposisi media dan ZPT air kelapa memberikan pengaruh nyata terhadap waktu muncul tunas stek pucuk. Karena faktor interaksi komposisi media dan ZPT air kelapa memberikan pengaruh nyata, maka untuk mengetahui perlakuan terbaik dilakukan uji jarak Duncan dengan signifikansi 5\%. Hasil uji lanjut Duncan terhadap waktu munculnya tunas dapat dilihat pada Tabel 3 .

Tabel 3. Hasil Uji Jarak Duncan Interaksi Komposisi Media dan ZPT Air Kelapa Terhadap waktu munculnya tunas (hari)

\begin{tabular}{cc}
\multirow{2}{*}{ Komposisi Media } & \multicolumn{2}{c}{ Waktu munculnya tunas (hari) } \\
\cline { 2 - 3 } & ZPT air kelapa Tanpa ZPT
\end{tabular}


Jurnal Biologi Universitas Andalas (J. Bio. UA.)

6(2) - September 2018: 98-106 (ISSN : 2303-2162)

\begin{tabular}{llc}
\hline Tanah & $41,33 \mathrm{~d}$ & $41,33 \mathrm{~d}$ \\
\hline Tanah + Sekam & $67 \mathrm{~b}$ & $51,33 \mathrm{c}$ \\
\hline $\begin{array}{l}\text { Tanah + Pupuk } \\
\text { kandang }\end{array}$ & $75,667 \mathrm{a}$ & $43 \mathrm{~d}$ \\
\hline \multicolumn{2}{l}{ Tanah + Pasir } & \\
\hline $\begin{array}{l}\text { Keterangan : Angka yang diikuti oleh huruf yang sama } \\
\text { pada setiap kolom untuk setiap parameter yang } \\
\text { diamati, tidak berbeda nyata pada taraf 5\%. }\end{array}$
\end{tabular}

Dari tabel 3 dapat dilihat bahwa waktu muncul tunas stek pucuk jeruk kacang lebih cepat tumbuh pada 4 perlakuan yaitu; menggunakan komposisi media campuran tanah dan pupuk kandang (1:1) tanpa ZPT air kelapa; menggunakan media tanah tanpa ZPT air kelapa; menggunakan media tanah dengan ZPT air kelapa dan menggunakan media campuran tanah dan pasir (2:1) tanpa ZPT Air kelapa. keempat perlakuan tersebut menunjukkan hasil yang tidak berbeda nyata terhadap waktu munculnya tunas. Dari hasil penelitian dapat diketahui bahwa pemberian zat pengatur tumbuh tidak memberikan pengaruh terhadap pertumbuhan tunas stek pucuk jeruk kacang. Sesuai dengan pendapat Nanda dan Anand (1970) bahwa pengaruh zat pengatur tumbuh akan lebih baik jika di dukung oleh media tanam yang optimal, karena media tanam menyediakan unsur hara yang diperlukan tanaman, sedangkan zat pengatur tumbuh akan memobilisasi unsur hara tersebut untuk proses rejuvinasi tunas.

\section{Panjang tunas}

Berdasarkan hasil analisa statistik menggunakan Two Way ANOVA dengan signifikansi 0.05 atau 5\% dapat diketahui bahwa interaksi antara Komposisi media dan ZPT air kelapa berpengaruh secara signifikan terhadap panjang tunas stek pucuk jeruk kacang (Citrus reticulata $\mathrm{Blanco}$ ). Hal ini ditunjukkan oleh $\mathrm{F}_{\text {hitung }}$ $>F_{\text {tabel }}$ pada interaksi antara variasi komposisi media dan ZPT air kelapa yaitu 174,248 > 3,34 artinya perlakuan komposisi media dan ZPT air kelapa memberikan pengaruh nyata terhadap panjang tunas stek pucuk. Karena faktor interaksi antara komposisi media dan ZPT air kelapa memberikan pengaruh nyata, maka untuk mengetahui perlakuan terbaik dilakukan uji jarak Duncan dengan signifikansi 5\%. Hasil uji lanjut Duncan terhadap panjang tunas dapat dilihat pada Tabel 4.

Tabel 4. Hasil Uji Jarak Duncan Interaksi Komposisi Media dan ZPT Air Kelapa Terhadap Panjang tunas $(\mathrm{cm})$

\begin{tabular}{lcc}
\hline \multirow{2}{*}{ Komposisi Media } & \multicolumn{2}{c}{ Panjang tunas $(\mathrm{cm})$} \\
\cline { 2 - 3 } & ZPT air kelapa & Tanpa ZPT \\
\hline Tanah & $6,567 \mathrm{~b}$ & $6,667 \mathrm{~b}$ \\
\hline Tanah + Sekam & $0,767 \mathrm{c}$ & $6,79 \mathrm{~b}$ \\
\hline $\begin{array}{l}\text { Tanah + Pupuk } \\
\text { kandang }\end{array}$ & $0,567 \mathrm{c}$ & $9,433 \mathrm{a}$ \\
\hline Tanah + Pasir & 0,567 & $6,567 \mathrm{~b}$ \\
\hline
\end{tabular}

Keterangan : Angka yang diikuti oleh huruf yang sama pada setiap kolom untuk setiap parameter yang diamati, tidak berbeda nyata pada taraf $5 \%$.

Dari Tabel 4 dapat dilihat bahwa perlakuan dengan penggunaan media campuran tanah dan pupuk kandang (1:1) tanpa ZPT air kelapa memberikan pengaruh yang berbeda nyata terhadap perlakuan yang lain. Media tanah dan pupuk kandang sangat mendukung pertumbuhan tunas stek pucuk jeruk kacang sehingga tunas stek pucuk memiliki panjang $9,433 \mathrm{~cm}$ lebih panjang dari media yang lain. Pada perlakuan dengan penggunaan media campuran tanah dan sekam (2:1) dengan ZPT air kelapa, perlakuan media campuran tanah dan pupuk kandang (1:1) dengan ZPT air kelapa dan perlakuan media campuran tanah dan pasir (2:1) dengan ZPT air kelapa memberikan hasil panjang tunas terendah dibandingkan perlakuan yang lain. Dari hasil penelitian Kristina (2012) tentang analisis kandungan ZPT endogeneous (sitokini dan auksin) dari air kelapa yang dilakukan dengan menggunakan teknik HPLC. Pada kelapa muda yang kondisi endospermanya masih seperti susu, kandungan sitokinin maupun auksin alami sangat tinggi. Seiring dengan bertambahnya umur kelapa, kandungan ZPT alaminya juga akan berkurang. ZPT alami pada air kelapa bersifat 
Jurnal Biologi Universitas Andalas (J. Bio. UA.)

6(2) - September 2018: 98-106 (ISSN : 2303-2162)

termolabil (mudah terurai bila dipanaskan pada suhu tinggi). Pada perlakuan yang stek pucuk jeruk kacang direndam dengan air kelapa 25\%, kemungkinan kandungan sitokinin yang terdapat pada stek tersebut telah terurai karena media tanah dengan penambahan pasir dan pupuk kandang memiliki suhu yang tidak stabil sehingga dapat mendegradasi ZPT alami air kelapa.

\section{Jumlah tunas}

Jumlah tunas baru yang dihitung pada stek jeruk kacang adalah tunas dengan panjang minimal $0,5 \mathrm{~cm}$ diakhir penelitian. Berdasarkan hasil analisa statistik menggunakan Two Way ANOVA dengan signifikansi 0.05 atau 5\% dapat diketahui bahwa interaksi antara Komposisi media dan ZPT air kelapa berpengaruh secara signifikan terhadap jumlah tunas stek pucuk jeruk kacang (Citrus reticulata Blanco). Hal ini ditunjukkan oleh $\mathrm{F}_{\text {hitung }}>\mathrm{F}_{\text {tabel }}$ pada interaksi antara variasi komposisi media dan ZPT air kelapa yaitu 13,434>3,34 artinya perlakuan komposisi media dan ZPT air kelapa memberikan pengaruh nyata terhadap jumlah tunas stek pucuk. - Karena faktor komposisi media dan ZPT air kelapa memberikan pengaruh nyata, maka untuk mengetahui perlakuan terbaik dilakukan uji jarak Duncan dengan signifikansi 5\%. Hasil uji lanjut Duncan terhadap panjang tunas dapat dilihat pada Tabel 5.

Tabel 5. Hasil Uji Jarak Duncan Interaksi Komposisi Media dan ZPT Air Kelapa Terhadap Jumlah tunas

\begin{tabular}{lcc}
\hline \multirow{2}{*}{ Komposisi Media } & \multicolumn{2}{c}{ Jumlah tunas } \\
\cline { 2 - 3 } & ZPT air kelapa & Tanpa ZPT \\
\hline Tanah & $2,667 \mathrm{c}$ & $5 \mathrm{bc}$ \\
\hline Tanah + Sekam & $3,333 \mathrm{c}$ & $6 \mathrm{~b}$ \\
\hline $\begin{array}{l}\text { Tanah + Pupuk } \\
\text { kandang }\end{array}$ & $1 \mathrm{~cd}$ & $11 \mathrm{a}$ \\
\hline Tanah + Pasir & $1 \mathrm{~cd}$ & $2,667 \mathrm{c}$ \\
\hline
\end{tabular}

Keterangan : Angka yang diikuti oleh huruf yang sama pada setiap kolom untuk setiap parameter yang diamati, tidak berbeda nyata pada taraf 5\%.
Dari tabel 5 diketahui bahwa perlakuan dengan penggunaan media campuran tanah dan pupuk kandang (1:1) tanpa ZPT air kelapa memberikan pengaruh yang berbeda nyata terhadap perlakuan yang lain. Perlakuan ini memiliki rata-rata jumlah tunas paling tinggi dibandingakan tiga media yang lain. Pupuk kandang yang ditambahkan pada media memberikan unsur hara $\mathrm{N}, \mathrm{P}$ dan $\mathrm{K}$ bagi stek pucuk jeruk kacang. Unsur-unsur hara tersebut sebagai pendorong pertumbuhan jumlah tunas tanaman.

\section{Jumlah daun yang baru muncul}

Berdasarkan hasil analisa statistik menggunakan Two Way ANOVA dengan signifikansi 0.05 atau 5\% dapat diketahui bahwa interaksi antara Komposisi media dan ZPT air kelapa berpengaruh secara signifikan terhadap jumlah daun stek pucuk jeruk kacang (Citrus reticulata Blanco). Hal ini ditunjukkan oleh $\mathrm{F}_{\text {hitung }}$ $>F_{\text {tabel }}$ pada interaksi antara variasi komposisi media dan ZPT air kelapa yaitu 20,546 > 3,34 artinya perlakuan komposisi media dan ZPT air kelapa memberikan pengaruh nyata terhadap jumlah daun stek pucuk. Karena faktor komposisi media dan ZPT air kelapa memberikan pengaruh nyata, maka untuk mengetahui perlakuan terbaik dilakukan uji jarak Duncan dengan signifikansi 5\%. Hasil uji lanjut Duncan terhadap panjang tunas dapat dilihat pada Tabel 6.

Tabel 6. Hasil Uji Jarak Duncan Interaksi Komposisi Media dan ZPT Air Kelapa Terhadap Jumlah Daun Baru

\begin{tabular}{lcc}
\multirow{2}{*}{ Komposisi Media } & \multicolumn{2}{c}{ Jumlah Daun Baru } \\
\cline { 2 - 3 } & ZPT air kelapa & Tanpa ZPT \\
\hline Tanah & $3,633 \mathrm{bc}$ & $4,667 \mathrm{~b}$ \\
\hline Tanah + Sekam & $2,133 \mathrm{c}$ & $4,967 \mathrm{~b}$ \\
\hline $\begin{array}{l}\text { Tanah + Pupuk } \\
\text { kandang }\end{array}$ & $1 \mathrm{~d}$ & $10,117 \mathrm{a}$ \\
\hline Tanah + Pasir & $1 \mathrm{~d}$ & $3,633 \mathrm{bc}$ \\
\hline
\end{tabular}

Keterangan : Angka yang diikuti oleh huruf yang sama pada setiap kolom untuk setiap parameter yang diamati, tidak berbeda nyata pada taraf 5\%. 
Jurnal Biologi Universitas Andalas (J. Bio. UA.)

6(2) - September 2018: 98-106 (ISSN : 2303-2162)
Pada tabel 6 memperlihatkan bahwa perlakuan dengan penggunaan media campuran tanah dan pupuk kandang (1:1) tanpa ZPT air kelapa memberikan respon yang lebih baik dan berbeda nyata dengan perlakuan lain terhadap jumlah daun yang baru muncul. Banyaknya daun pada tunas perbibit disebabkan oleh pertumbuhan tunas yang baik. Jumlah daun erat kaitannnya dengan panjang tunas. Semakin panjang tunas semakin banyak daun yang dihasilkan. Jumlah daun akan bertambah seiring dengan panjang tunas, karena stek yang mempunyai tunas lebih panjang menyebabkan bertambahnya jumlah ruas dan buku tempat tambahnya daun (Karnedi 1998).

\section{Panjang akar terpanjang dan Jumlah Akar}

Panjang akar terpanjang dan jumlah akar tidak dianalisis secara statistik hanya analisa deskriptif. Berdasarkan hasil penelitian dapat dilihat bahwa perlakuan A3B0 adalah perlakuan yang memberikan hasil panjang akar dan jumlah akar yang terbaik yaitu sebesar 13,9 cm dengan jumlah akar 13,9 buah akar. Sedangkan perlakuan perlakuan A2B1, A3B1 dan A4B1 belum memperlihatkan pertumbuhan akar (Gambar 1 dan 2).

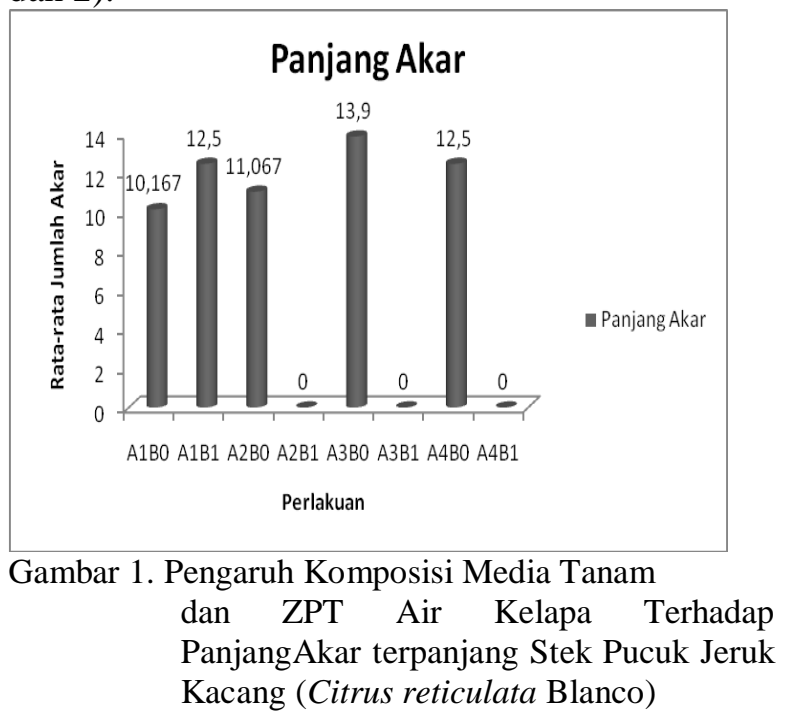

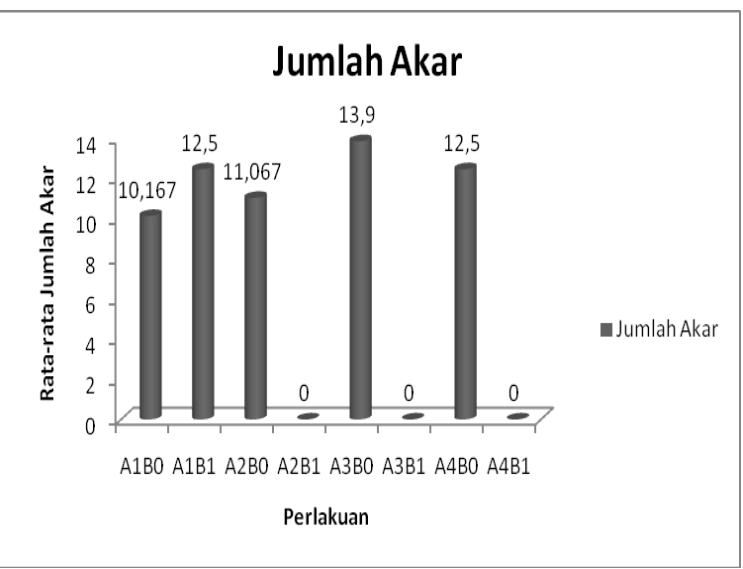

Gambar 2. Pengaruh Komposisi Media Tanam dan ZPT Air Kelapa Terhadap Jumlah Akar Stek Pucuk Jeruk Kacang (Citrus reticulata Blanco)

Terbentuknya akar pada stek merupakan indikasi keberhasilan dari stek. Adapun hal-hal yang mempengaruhi keberhasilan pertumbuhan akar pada stek adalah faktor lingkungan dan faktor dari dalam tanaman.

a. Faktor lingkungan

Faktor lingkungan yang mempengaruhi keberhasilan pertumbuhan stek yaitu: media perakaran, suhu, kelembaban, dan cahaya (Hartman, 1983). Media perakaran berfungsi sebagai pendukung stek selama pembentukan akar, memberi kelembaban pada stek, dan memudahkan penetrasi udara pada pangkal stek. Media perakaran yang baik menurut Hartman (1983) adalah yang dapat memberikan aerasi dan kelembapan yang cukup, berdrainase baik, serta bebas dari patogen yang dapat merusak stek. Media perakaran berfungsi sebagai pendukung stek selama pembentukan akar, memberi kelembaban pada stek, dan memudahkan penetrasi udara pada pangkal stek.

Beberapa media perakaran stek yang dilakukan adalah tanah subsoil, tanah topsoil, pupuk kandang, dan kompos. Pupuk kandang dapat memperbaiki sifat fisik tanah sehingga dapat menunjang pertumbuhan dan perkembangan akar tanaman didalam pembibitan. Peranan dari pupuk kandang ini dapat mengembangkan beberapa unsur hara seperti 
Jurnal Biologi Universitas Andalas (J. Bio. UA.)

6(2) - September 2018: 98-106 (ISSN : 2303-2162) fosfor, nitrogen, sulfur, dan kalium, dan meningkatkan kapasitas tahan kation tanah. Disamping itu pupuk kandang dapat melepaskan unsur $\mathrm{P}$ dari oksida $\mathrm{Fe}$ dan $\mathrm{Al}$, dan dapat memperbaiki sifat - fisik dan struktur tanah, serta dapat membentuk senyawa kompleks dengan unsur makro dan mikro sehingga dapat mengurangi proses pencucian unsur.

Suwardjono, (2003) mengatakan bahwa pemberian pupuk kandang dapat memperbaiki sifat fisik tanah sehinga, dapat menunjang pertumbuhan dan perkembangan perakaran tanaman. Peranan dari pupuk kandang antara lain (1) mengembangkan beberapa unsur hara seperti fosfor, nitrogen, sulfur, dan kalium, (2) meningkatkan kapasitas tukar kation tanah, (3) melepaskan unsur $\mathrm{P}$ dari oksida $\mathrm{Fe}$ dan $\mathrm{Al}$, (4) memperbaiki sifat fisik dan struktur tanah, dan (5) membentuk senyawa kompleks dengan unsur makro dan mikro sehingga dapat mengurangi proses pencucian unsur.

b. Faktor bahan stek

Kondisi fisiologis tanam mempengaruhi penyetekan adalah umur bahan stek, jenis tanaman, adanya tunas dan daun muda pada stek, persediaan bahan makanan, dan zat pengatur tumbuh. Adanya tunas dan daun pada stek berperan penting bagi perakaran. Bila seluruh tunas dihilangkan maka pembentukan akar tidak terjadi sebab tunas berfungsi sebagai auksin. Selain itu, tunas menghasilkan suatu zat berupa auksin yang berperan dalam mendorong pembentukan akar yang dinamakan Rhizokalin (Hartman, 1983). Perlakuan A3B0 memiliki jumlah tunas terbanyak sehingga akar stek tumbuh lebih banyak pada perlakuan tersebut, sedangakan perlakuan A2B1, A3B1 dan A4B1 memiliki tunas yang sedikit dan pendek.

\section{Kesimpulan}

Berdasarkan hasil penelitian dapat disimpulkan bahwa perlakuan A3B0 dengan komposisi media tanam tanah dan pupuk kandang (1:1) tanpa pemberian ZPT air kelapa memberikan pengaruh terbaik terhadap pertumbuhan stek pucuk jeruk kacang (Citrus reticulata Blanco). Hal ini dapat dilihat dari pengamatan persentase bibit hidup, waktu muncul tunas, jumlah tunas, panjang tunas, jumlah daun yang baru muncul, jumlah akar dan panjang akar terpanjang.

\section{Daftar Pustaka}

Bridwell, R.G.S. 1979. Plant Physiology.Mc. Millan Co. Inc., New York. $251 \mathrm{p}$

Fanesa, Anggia. 2011. Pengaruh Pemberian Beberapa Zat Pengatur Tumbuh Terhadap Pertumbuhan Setek Pucuk Jeruk Kacang (Citrus nobilis L).

Hartman dan Kester. 1983. Plant Propagation Principle and Practice Prentice Hall International Inc Engelwoods Clifs New Jersy.

Karnedi. 1998. Pengaruh Konsentrasi Urine Sapi Terhadap Pertumbuhan Bibit Panili (Vanila planifora Andrew). (skripsi). Padang. Fakultas Pertanian Universitas Andalas. 45 hal.

Kristina, N. N dan S F SYAHID. 2012. Pengaruh Air Kelapa Terhadap Multiplikasi Tunas In Vitro, Produksi Rimpang dan Kandungan Xanthorrhizol Temulawak Di Lapangan. Jurnal Littri 18(3), 125-134

Manner HI, Buker RS, Smith VE, Word D, Elevitch CR. 2006. Species Profiles for Pacific Island Agroforestry. Citrus (citrus) and fortunella (kumquat) Hawai'i (US). http://agroforestry.net/tti/citrus-citrus.pdf.

Nanda, KK and Anand, JK. 1970. Seasonal Change in Axuin Effect on Rooting of Populus nigra and its Relationship with 
Jurnal Biologi Universitas Andalas (J. Bio. UA.)

6(2) - September 2018: 98-106 (ISSN : 2303-2162)

mobilistation of starch. Ann. Rev Plant Physiol 23: 99-107

Nasir. N, Takakura. A, Kitajima. A, Yamamoto. M. 2017. Genetic Identification of "Limau Kacang" (Citrus sp), a local mandarin cultivaed in West Sumatra by Sequence related amplified polymorphisme. Fruits. Vol 72 Issue 2, p104-108.

Oksana. Rahmadani, Elfi. Syamsul. 2011. Peranan Berbagai Media Tumbuh Bagi Pertumbuhan Stek Daun Jeruk J.C (Japanche citroen) dengn Beberapa Konsentrasi ZAP. Fakultas Pertanian dan Peternakan UIN SUSKA Riau.

Pamungkas, F.T., Darmanti, S., dan Raharjo, B. 2009. Pengaruh Konsentrasi dan Lama Perendaman Dalam Supernatan Kultur Bacilus Sp.2 DUCC-BR-KI 3 Terhadap Pertumbuhan Stek Horizontal Batang Jarak Pagar (Jatropha curcas L.). (Online). (http://eprints.undip.ac.id/2352/1/Publikasi Febri Jadi.pdf).

Suwardjono. 2003. Pengaruh Beberapa Jenis Pupuk Kandang Terhadap Pertumbuhan dan Produksi Kacang Tanah. Jurnal Matematika, Sains dan Technologi 2 (2) hal 1-5. 